\title{
ELEITOS VERSUS PECADORES: O IDEAL CAVALEIRESCO N’ A DEMANDA DO SANTO GRAAL
}

\section{ELECTECD VERSUS SINNERS: CHILVARIC IDEAL IN THE QUEST FOR THE HOLY GRAIL}

\author{
Adriana Maria de Souza Zierer ${ }^{1}$
}

\begin{abstract}
RESUMO: $O$ objetivo do artigo é discutir as imagens dos cavaleiros medievais através da novela de cavalaria anônima $A$ Demanda do Santo Graal (século XIII). Sabendo da importância da cavalaria na Idade Média, os grupos dirigentes pretendiam controlar esta instituição, ou, segundo o sociólogo Nobert Elias, "civilizar" a sua agressividade. Neste sentido, serão analisados os principais cavaleiros da narrativa e seus atributos. Galaaz, nome de ascendência bíblica que significa 0 "puro dentre os puros" é o cavaleiro eleito para encontrar o Santo Vaso. A maior parte dos cavaleiros, no entanto é composta por pecadores, como o próprio pai de Galaaz, Lancelot. As faltas dos cavaleiros estão ligadas aos sete pecados mortais.
\end{abstract}

PALAVRAS-CHAVE: cavaleiro, salvação, pecado, A Demanda do Santo Graal

ABSTRACT: The purpose of this paper is to discuss the image of medieval knights through the anonymous roman of chivalry The Quest for the Holy Grail (13 $13^{\text {th }}$ century). The ruling groups sought to control this institution, or as the sociologist Norbert Elias, "civilize" its aggressiveness. In this sense, we will analyze the main knights in the narrative and their attributes. Galahad, descent biblical name which means "pure from the pure" is the elected one to find the Holy Vessel. Most knights, however, are sinners, as the father of Galahad, Lancelot. Transgressions of the knights are connected to the seven deadly sins.

KEYWORDS: knight, salvation, sin, The Quest for the Holy Grail

(recebido em 20/01/2013, aprovado em 13/05/2013)

\section{Introdução}

A Demanda do Santo Graal é uma novela de cavalaria anônima que faz parte da Matéria da Bretanha, conjunto de textos de origem bretã e fundo céltico, tratando principalmente do rei Artur e dos cavaleiros da távola redonda. A narrativa pertence ao códice 2594 da Biblioteca Nacional de Viena e foi traduzida do francês para o português em meados do século XIII. Neste momento de prosificação da Matéria da Bretanha (passagem dos textos de poesia para prosa), esses relatos foram também cristianizados, com o objetivo de controlar a agressividade da nobreza. Neste sentido, serão analisados os principais cavaleiros da narrativa e seus atributos. 0 modelo indicado é o do bom cristão, obediente à Igreja e que tem sucesso nas suas ações. Por isso, no manuscrito, enquanto a maior parte dos membros da távola redonda são pecadores, isto é, "maus cavaleiros", Galaaz e seus companheiros são os eleitos e que podem ter acesso ao Santo Vaso.

Este estudo tem por ótica o estudo do imaginário que, segundo Schmitt é "uma realidade coletiva que consiste em narrativas míticas, ficções, imagens, compartilhadas pelos atores sociais.

\footnotetext{
1 Doutora em História. Docente de História Medieval da Universidade Estadual do Maranhão (UEMA) e professora colaboradora do Mestrado em História Social da Universidade Federal do Maranhão (UFMA). É uma das coordenadoras dos grupos de pesquisa Brathair - Grupo de Estudos Celtas e Germânicos e Mnemosyne - Laboratório de História Antiga e Medieval. Coordenadora do projeto de pesquisa Representações do Cavaleiro no Imaginário Medieval, desenvolvido entre 2006-2012, com a participação de alunos de inicação científica.
} 
Toda sociedade, todo grupo produz um imaginário, sonhos coletivos garantidores de sua coesão e de sua identidade" (SCHMITT, 2007, p. 351).

Para Le Goff, o imaginário vai além do conceito de representação, tendo ligações com 0 simbólico e o ideológico, e possui como fontes privilegiadas as literárias e artísticas (LE GOFF, 1994, p. 11-12). Hervé Martin concorda com ele e enfatiza que a ideologia cavaleiresca pode ser estudada através de romances, canções e poemas. Daí a importância de dirigirmos o nosso estudo para uma novela de cavalaria, A Demanda do Santo Graal, que nos permite lançar um amplo olhar sobre 0 imaginário da cavalaria medieval. Sobre o conceito de ideologia, Duby afirma que podem ser globalizantes, estabilizadoras da ordem social, deformantes, no sentido de garantir os privilégios de quem detém o poder, concorrentes e conservadoras (DUBY, 1976, p. 131-134).

A ideologia cavaleiresca buscava apresentar um grupo de cavaleiros ideais como modelo aos nobres, estabilizar os conflitos dentro da nobreza na disputa por terras (nobres com/sem propriedades), garantir os privilégios de clero, dos aristocratas mais poderosos e dos reis em ascensão. Por fim, intentava conservar a estrutura social, de forma que, grupos desprivilegiados, como camponeses, trabalhadores urbanos e comerciantes em geral, não tivessem acesso à cavalaria, entendida como uma ordem superior e que somente poderia ser composta por elementos da nobreza. Em A Demanda do Santo Graal, os bons nobres, são os cavaleiros cristãos, obedientes ao clero e aos propósitos da instituição clerical.

O tema central do relato é a busca do Santo Graal, o cálice utilizado por Jesus na Última Ceia, que José de Arimatéia (ou um descendente seu) teria retido e usado para recolher o sangue vertido por Cristo na cruz, o qual fora depois conduzido ao reino de Logres. A ação dos cavaleiros da távola redonda na Demanda por esse objeto místico garantiria o (re) equilíbrio do reino arturiano, que havia perdido a sua prosperidade pelo afastamento do Santo Vaso.

Segundo a ótica cristã da narrativa, o Graal parte da corte devido aos pecados do rei e da maior parte de seus cento e cinquenta cavaleiros. Destes, apenas um número reduzido, conduzido pelo filho de Lancelot, conseguirão encontrar outra vez o Santo Graal. Galaaz, nome de ascendência bíblica que significa o "puro dentre os puros" é o cavaleiro eleito para encontrar o Santo Vaso, acompanhado de outros dois companheiros eleitos: Persival e Boorz. Além desses três, somente mais nove cavaleiros poderão ver outra vez o Santo Vaso, totalizando doze, em analogia com os apóstolos de Cristo.

\section{O Graal: Principal Propósito da Demanda}

A Demanda inicia-se com a produção de um acontecimento maravilhoso: a aparição do Santo Graal, relacionada com a luz, claridade na corte arturiana: 
E eles estando assim sentados, entrou no paço o Santo Graal, coberto de um veludo branco; mas não houve um que visse quem o trazia. E assim que entrou, foi o paço todo repleto de bom odor, como se todos os perfumes do mundo lá estivessem. E por onde passava, logo todas as mesas ficavam repletas de tal manjar, qual em seu coração desejava cada um. (DSG, 1988, p. 41)

O Graal era capaz de alimentar tanto espiritualmente quanto materialmente aqueles que se servissem dele e é apresentado como principal elemento da prosperidade e harmonia do reino de Artur. Assim, o Santo Graal, oriundo inicialmente de antigas tradições célticas, como o caldeirão da abundância, representa ao mesmo tempo um alimento terreno e divino e no manuscrito fornece um simbolismo cristão. Logo depois de aparecer na corte, porém, o objeto sagrado parte, devido aos pecados do rei e de seus cavaleiros. Começa então a busca na qual somente os eleitos serão vencedores.

As narrativas célticas fazem menção ao caldeirão da abundância, que possui analogias com 0 Graal, onde, por mais que se retirassem alimentos, eles nunca acabavam. No poema Os Despojos do Outro Mundo (Preideu Annwvyn), escrito no século X, Artur volta somente com sete homens após uma malograda expedição ao Outro Mundo onde tentara obter este objeto.

Outras narrativas contidas no Mabinogion (conjunto de contos celtas) mencionam o caldeirão do renascimento. Ao ser colocado no caldeirão um guerreiro morto poderia reviver, mas perderia a voz. Haveria também o caldeirão do sacrifício, onde os maus reis seriam jogados, segundo a tradição celta (LE ROUX; GUYONVARC'H, 1990, p. 63).

Interessante observar que nas primeiras narrativas acerca do Graal é Persival e não Galaaz o eleito para encontrá-lo. É o caso da obra Perceval, ou o Romance do Graal, de Chrétien de Troyes, no qual o Graal é apresentado como um prato sendo levado num cortejo no qual aparece também uma lança que sangra. O Graal nesta obra já possui elementos curativos e alimentares uma vez que este era o único alimento consumido por um tio do eleito.

Embora o Graal nesta obra ainda não tenha atingido toda a sua simbologia cristã, já está associado ao Cristianismo. Persival também é o cavaleiro principal na trilogia de Robert de Boron que deu origem à vulgata da Matéria da Bretanha². Porém com a prosificação das narrativas no chamado ciclo da vulgata um personagem mais perfeito aparece, é Galaad (Galaaz), que fica em primeiro plano.

Robert de Boron foi o primeiro a cristianizar a saga arturiana. Escreveu três obras que se perderam. Com base em suas obras foram escritos cinco romances anônimos (a vulgata da Matéria da Bretanha) no século XIII, dentre os quais está A História do Santo Graal, A História de Merlim, O Livro de Lancelot do Lago, A Demanda do Santo Graal e A Morte do Rei Artur. Na obra de Boron é Persival e não Galaad o cavaleiro eleito que encontra o Santo Graal. 
A Demanda guarda tanto resquícios da tradição celta sobre o simbolismo do Graal como significados cristãos através do simbolismo da missa, quando a hóstia e o vinho se tornam o corpo e 0 sangue de Cristo.

Vejamos inicialmente os elementos da cavalaria no período medieval para compreendermos o papel dos membros da távola redonda n' A Demanda do Santo Graal.

\section{A Cavalaria e a Ideologia Cavaleiresca}

A palavra cavaleiro vem do termo latino miles, utilizado a partir do ano mil nas línguas vulgares para distinguir uma nova categoria social do resto dos homens, o chevalier, Ritter ou knight. Nesta época o cavaleiro é o detentor dos instrumentos necessários para vencer o combate, graças à superioridade do cavalo, da armadura e das armas. A partir do século XII houve uma tendência à fusão entre nobreza e cavalaria. Por isso, nosso olhar é para o cavaleiro como pertencente à nobreza.

Outro aspecto é que desde fins do século $X$ a Igreja buscou 0 controle da violência através de conceitos como o da Paz de Deus (não atacar os inermes - clérigos e indefesos) e Trégua de Deus (proibição de lutas alguns dias na semana e durante os dias santos) (CARDINI, 1989, p. 58-59).

Também desde Santo Agostinho houve a busca pelo controle do uso da violência, uma vez que o cristianismo em sua essência era pacífico e Jesus afirmava a necessidade de dar a "outra face" ao invés de revidar com violência a ação sofrida. Santo Agostinho criou a noção de "guerra justa" que só poderia ocorrer na defesa da paz e se fosse determinada por autoridade competente. De acordo com São Bernardo no século XII, a luta contra os muçulmanos deixa de ser um homicidium (morte de um homem) e se tornava um malicidum (eliminação de um mal) (CARDINI, 2002, p. 476). Assim, a Cruzada se tornou tanto uma guerra justa, segundo concepção elaborada por Santo Agostinho, como uma guerra santa, de acordo com o pensamento de São Bernardo (ZIERER, 2012, p. 39)

A canalização da agressividade bélica para as Cruzadas na Terra Santa e as lutas contra os hereges e infiéis na Europa foi um meio de tentar diminuir a violência que ameaçava a sociedade e garantir terras aos secundogênitos, desprovidos de propriedades na Idade Média Central. Por isso, além de, pela ótica da Cruzada, o guerreiro se tornar um miles christi (cavaleiro de Cristo) que deveria lutar contra os infiéis e ter os seus pecados perdoados, a Igreja buscou cada vez mais cristianizar a cerimônia de sagração do cavaleiro. Este deveria fazer uma noite de vigília, tomar um banho purificador e rezar. No dia seguinte antes da cerimônia havia uma missa e as armas eram abençoadas pelo padre. Após a cerimônia o cavaleiro deveria entregar presentes aos convidados. 
No entanto, esta cerimônia ficou cada vez mais cara e dedicada aos filhos de reis e nobres importantes. Muitos membros da nobreza não tiveram condições econômicas para se tornar cavaleiros, ficando a vida toda na condição de escudeiros.

Os nobres também procuraram desde o século XII fechar o acesso da cavalaria a pessoas que não tivessem origens nobiliárquicas. Nos séculos XII e XIII com o fortalecimento das monarquias capetíngia e plantageneta ocorreu um desejo de controle da agressividade da nobreza pelos poderes constituídos, ao mesmo tempo em que a própria aristocracia desejava se destacar de outros grupos sociais como o campesinato e a burguesia (MARTIN, 1996, p. 299). Neste sentido é que foram elaborados desde este período os manuais de comportamento cavaleiresco na corte, ensinando como os cavaleiros deveriam se portar à mesa e como tratar as damas, a cortesia.

Já outros grupos sociais eram ridicularizados nas obras literárias, especialmente o camponês, "vilão", visto como desprovido de sentimentos, assim como os comerciantes e banqueiros eram apresentados como desprovidos de boa educação, coragem, valentia e honra, todos estes atributos associados ao modo de viver em corte e essencialmente relacionados à nobreza.

Nos romances de cavalaria em verso do século XII o mais importante são as ações dos cavaleiros da távola redonda, apresentados como ideais de cavaleiros corteses. Destes, o mais importante é o Lancelote do Lago, que aparece pela primeira vez na obra Le Chevalier de la Charrete ( $O$ cavaleiro da Carreta), de Chrétien de Troyes.

Já no século XIII é construído ao lado do modelo do cavaleiro cortês, a ideia de que a defesa do cristianismo é o elemento mais importante para o bom cavaleiro. Neste sentido, o amor cortês é criticado e a virgindade e a fidelidade aos ideais cristãos são valorizados em algumas obras literárias, numa aproximação dos cavaleiros com o ideal das ordens militares, como os templários. Este é ao mesmo tempo um momento em que a cavalaria como instituição encontra-se em crise em virtude da perda nas Cruzadas. Daí a necessidade de revalorização do caráter cruzadístico dos cavaleiros, visando conter a agressividade deste grupo social.

Dois exemplos de prosa sobre o cavaleiro cristão são: o manual do filósofo catalão Ramon Llull, intitulado o Livro da Ordem de Cavalaria, com as normas de como os bons cavaleiros deveriam se comportar, pautados no cristianismo, e o nosso objeto de estudo, a novela de cavalaria $A$ Demanda do Santo Graal, na qual o principal herói é o filho de Lancelot, e seu oposto simbólico, Galaaz.

O filósofo catalão Ramon Llull compôs o Livro da Ordem de Cavalaria (1279-1283), obra que procura apresentar as qualidades que os cavaleiros deveriam possuir e ao mesmo tempo justificar a ordem vigente, criticando a possibilidade de outros grupos sociais que não pertencessem a aristocracia 
se tornassem cavaleiros. De acordo com o autor, "linhagem e cavalaria se convém e se concordam" (LLULL, 2000, p. 53).

O camponês por não possuir origem nobre, segundo a visão do autor, não poderia fazer parte da ordem da cavalaria. Llull afirma que os cavaleiros necessitavam das "gentes" para que arassem as terras (LLULL, 2000, p. 17), o que justificava a organização social divida em oratores, bellatores e laboratores, segundo concepções como a do bispo Adalberón de Laon (século XI). Este último pode ser considerado um dos ideólogos da teoria da tripartição dos poderes na Idade Média, analisada por Georges Duby em sua obra As Três Ordens ou o Imaginário do Feudalismo. O bispo de Laon, entre outros pensadores medievais, defendia que cada ordem social necessitava da outra, sendo a função dos clérigos (oratores) rezar pela salvação da sociedade, a dos nobres (bellatores) defender a todos os grupos e a dos camponeses (laboratores) sustentar a sociedade com o seu trabalho (DUBY, 1982). Ramon Llull demonstra em seu escrito concordar com a organização social vigente, sendo terminantemente contrário que os trabalhadores do campo se tornassem cavaleiros e/ou casassem com mulheres da nobreza.

Em seu manual, Llull também defende a submissão dos homens do campo à nobreza como forma de pacificação e bom funcionamento da sociedade. Argumentava que os camponeses deviam ter medo dos cavaleiros: "pelo pavor que as gentes têm dos cavaleiros, duvidam em destruir as terras" (LLULL, 2000, p. 63). No entanto, após apontar os maus nobres que atacavam mulheres e matavam camponeses, afirma que "cavaleiro que não tenha olhos para ver os fracos, nem coração para pensar em suas necessidades, não é verdadeiro cavaleiro nem está na Ordem de Cavalaria" (LLULL, 2000, p. 39).

As ações violentas no século XIII, como, por exemplo, a busca de terras por nobres secundogênitos através de guerras privadas, colocavam a sociedade em risco. Daí o ideal do cavaleiro totalmente voltado à defesa do cristianismo, representado pelo cavaleiro ideal proposto por Llull e por Galaaz, na Demanda, como um elemento importante da conservação das estruturas sociais. Por isso, em A Demanda do Santo Graal ocorre uma crítica ao ideal do amor cortês, representado pela figura de Lancelot.

Enquanto este tem como missão principal servir a sua dama, Guinevere (Genevra), de acordo com as regras do amor cortês, o objetivo principal de Galaaz é a sua fidelidade ao cristianismo, a defesa contra os infiéis e a manutenção da sua alta espiritualidade, expressas na sua virgindade, no uso da estamenha (túnica de lã com farpas, usada pelos penitentes) e em suas ações de orar, jejuar e glorificar a Deus. Tais elementos o tornam o cavaleiro ideal da Demanda, pronto a levar a bom termo as aventuras. 
Poucos são cavaleiros eleitos que veem o Graal uma segunda vez. Além dos três principais: Galaaz, Persival e Boorz; outros três: Elaim o Branco, Lambeguez e Pinabel da Ínsua. E somando a eles mais seis cavaleiros que passam a integrar o grupo dos eleitos depois de iniciada a Demanda (Palamades, Melians de Dinamarca, Artur o Pequeno, Claudim, Meraugis de Porlegues e Persidos de Calaz) (FERNANDES, 2010, p. 3).

Quanto aos demais cento e trinta e oito cavaleiros da távola redonda, eram pecadores e não conseguem atingir o Santo Vaso. Segue o quadro dos principais vícios dos não eleitos no romance (Quadro 1):

Quadro 1. PRINCIPAIS VÍCIOS DOS CAVALEIROS N'A DEMANDA DO SANTO GRAAL

\begin{tabular}{|l|l|}
\hline CAVALEIROS & VÍCIOS \\
\hline LANCELOT & LUXÚRIA \\
TRISTÃO & \\
\hline GALVÃO & LUXÚRIA \\
MORDERET & INVEJA \\
AGRAVAIM & ORGULHO \\
& MENTIRA \\
\hline EREC & ORGULHO \\
\hline LEONEL & IRA \\
\hline
\end{tabular}

O principal vício apontado tanto por Llull como na Demanda é a luxúria, mas nessa narrativa podemos ver cavaleiros também tomados pela inveja, mentira, orgulho e ira. Vejamos a primeira oposição a seguir: castidade versus luxúria, representada por um eleito, Galaaz versus um pecador, seu pai Lancelot.

\section{Os Cavaleiros Eleitos: Galaaz em oposição a Lancelot}

Um primeiro exemplo na Demanda é a oposição entre o cavaleiro cortês e cristão na Demanda. A partir dos elementos deste primeiro modelo, é criado no século XII um conjunto ideal de comportamentos a serem adotados na corte: ser educado com as damas, corajoso, vencer os combates, saber portar-se à mesa e preocupar-se com os fracos.

Surgem os romances de cavalaria em verso de Chrétien de Troyes que se iniciam na corte do rei Artur para que logo depois os cavaleiros possam mostrar o seu valor. O rei aparece como mero árbitro e a ação se desenvolve essencialmente ligada aos feitos cavaleirescos. Dentre os heróis, 
Lancelot, criado por Chrétien aparece como o "melhor cavaleiro do mundo" 3 (CHRÉTIEN DE TROYES, 1991, p. 194).

Porém, esse cavaleiro mantém uma relação adúltera com Guinevere, esposa de Artur. No amor cortês o amante deve fazer tudo para agradar a sua dama. Como ela havia sido raptada, primeiro ele é convidado por um anão a viajar na "carroça da infâmia", destinada aos condenados, para saber o paradeiro da amada. Após uma curta hesitação de "dois passos", o herói aceita colocar a sua honra em risco e entra na carroça. Todas as suas ações visam a agradar a dama, de quem é vassalo. A recompensa do herói não é platônica, pois após salvá-la a paixão de ambos é consumada.

Segundo a concepção do amor cortês, o cavaleiro pode ser feito de marionete pela dama, satisfazendo todos os seus caprichos como prova de amor (MARTIN, 1996, p. 330-331). Assim, numa punição pela sua curta hesitação na "carroça da infâmia", Lancelot foi depois "castigado" por Guinevere. Ao participar de um torneio disfarçado somente para vê-la, recebe a mensagem para que ele perdesse todos os combates, também uma outra atitude humilhante a ser adotada pelo "melhor cavaleiro do mundo". Ele faz o que ela manda e obedece de novo quando sua senhora envia nova mensagem para que a partir dali vencesse os combates. O rei Artur não sabe da traição do casal e não ocorre castigo ao adultério realizado pelos amantes.

Enquanto nos romances em verso o herói não é punido pela felonia ao rei, na Demanda a moral cristã é valorizada e por este motivo o amor cortês é duramente criticado. Por este motivo Lancelot não é mais o principal cavaleiro da narrativa, mas sim seu filho Galaaz, puro e virgem.

Interessante observar a contradição na figura de Galaaz: ele é o eleito para encontrar o Santo Graal, mas ao mesmo tempo era filho bastardo de Lancelot com a filha do rei Peles. Sua concepção esteve associada ao uso de artes mágicas para que sua mãe seduzisse Lancelot. Na narrativa fica explicado que a eleição de um bastardo para realizar os altos feitos do Graal ocorre devido ao desejo de Deus em mostrar a alta espiritualidade do cavaleiro, ainda que este fosse fruto do pecado.

Quanto a Lancelot vários avisos the são dados durante a narrativa de que não iria encontrar 0 Santo Vaso devido aos seus pecados. O herói tenta, mas continua fiel ao amor cortês e fica consciente que havia perdido a salvação de sua alma devido ao amor por Guinevere. Inclusive tem um sonho no qual vê a si próprio e a amada queimando no inferno juntamente com Tristão e Isolda, outro casal adúltero que habitava a corte arturiana (DSG, 1995, p. 165). Somente quando a rainha Guivenere (Genevra) morre é que Lancelot vai purgar os seus pecados, se tornando ermitão e abrindo-se assim a possibilidade da sua salvação ao fim da narrativa.

"Ele venceu e sobrepujou todos os cavaleiros do mundo. A ele ninguém pode se comparar!" (CHRÉTIEN DE TROYES, 1991, p. 194) 


\section{Cavaleiros Eleitos: Superioridade de Galaaz em relação a Persival e Boorz}

No romance, o elemento mais valorizado é a castidade ou melhor, a virgindade. Por este motivo, Galaaz entre todos os cavaleiros é considerado o mais perfeito e o escolhido para dar cabo das aventuras do Santo Vaso. Já Persival é tentado uma vez e Boorz, por meio de feitiço, tem uma vez na vida relação sexual que gera descendência, Elaim, o Branco, um dos cavaleiros eleitos a ver novamente o Santo Graal.

A superioridade de Galaaz se apresenta com relação a seus dois companheiros porque não demonstra desejo sexual, ao contrário daqueles. Apesar de possuir a mácula de ser bastardo ele não apresenta pecados e está próximo da figura dos santos. Os eremitas, homens puros na narrativa que tem a função de desvendar as aventuras aos cavaleiros, confirmam o aspecto sobrenatural de Galaaz, uma vez que dizem que ele é uma coisa "santa e honrada" (DSG, I, 1955, p. 7).

Porém, além da bastardia, outro elemento o liga ao mundo material: a sua beleza, que está ligada tanto à natureza espiritual como material, já que atrai a cobiça feminina. Neste sentido é que ocorre o episódio no castelo do rei Brutus quando a filha do rei se apaixona por Galaaz e vai até o seu quarto no intuito de concluir o enlace amoroso. Rechaçada, a donzela ameaça matar-se com a espada do jovem. Ante isso, o cavaleiro titubeia e promete realizar o desejo da donzela para evitar que ela morresse, mesmo que desta maneira a sua salvação e o seu papel de eleito estivessem em risco (DSG, 1995, p. 94). No entanto, Deus permite que a donzela se mate e Galaaz se mantém puro.

Persival quase realiza o ato sexual com uma donzela "grega" (uma alusão ao paganismo) de quem se enamora ao encontrar num bosque durante a Demanda e a quem a narrativa explica, logo depois, ser o diabo feito à semelhança de donzela para enganar Persival e metê-lo em pecado mortal (DSG, 1995, 2002). Vem então uma voz do céu como manifestação divina, como único recurso para impedir Persival de cometer o pecado. O cavaleiro desmaia e ao acordar a donzela havia se transformado no demônio: "viu a donzela rir, e, quando a viu rir, maravilhou-se e logo entendeu que era o demo que lhe aparecera em semelhança de donzela polo enganar e o meter em pecado mortal" (DSG, 1995, p. 202) (grifo nosso).

Quanto a Persival na Demanda, sua pureza além de ser garantida pela proteção de Deus, no episódio da donzela-diabo é também mostrada pelo fato de uma vez um ermitão pedir que Persival o abençoasse (símbolo de sua pureza espiritual, uma vez que os ermitãos são considerados homens dotados de grande religiosidade). 
Este eremita conta a Persival que desejava cometer o suícidio ao saber que seu irmão morto, o qual também havia sido eremita, estava havia três anos sofrendo no purgatório. Porém ao saber da chegada do jovem puro, o religioso desistiu do seu intento e pediu a ele bênçãos, o que provava 0 caráter superior de Persival (DSG, 1995, p. 150).

Outro momento a demonstrar a pureza de Persival é quando Lancelot, após sonhar que estava no Inferno, acorda com a perna em chamas. É Persival que, ao colocar a mão ali consegue salvá-lo da dor e fazer a perna do companheiro parar de queimar (DSG, 1995, p. 165), mais um indício de seus dons de eleito de Deus. Ainda a ser ressaltado que assim como Galaaz, Persival também morrerá ao encontrar o Santo Graal em Sarras, no Oriente, após passar por um período como eremita por um ano antes de morrer.

Dos três eleitos, o único que retorna a Camelot é Boorz, voltando-se também ao eremitismo. Segundo Buescu, Persival é um herói mais humano que Galaaz, um eleito sem falhas (BUESCU, 1991, p. 189-190). Os dois companheiros de Galaaz atingem a santidade após provações e a entrada na vida religiosa (CHORA, 2012, p. 24). Já o "puro dos puros" é um predestinado que desde o início cumpre um destino já traçado.

Quanto a Boorz, embora durante a Demanda tenha uma conduta irrepreensível, rezando e jejuando durante o caminho, havia cometido o ato sexual uma única vez no passado em virtude de um feitiço realizado por uma jovem que desejava ter um filho da távola redonda. Desta união nasceu um filho bastardo, Elaim o Branco, que também será um dos doze cavaleiros a ver outra vez o Santo Graal. Boorz passa toda a Demanda se penitenciando do seu pecado e ao fim da Demanda torna-se ermitão, cumprindo assim o caminho da santificação.

Sobre os três cavaleiros eleitos e sua importância na Demanda, há ainda que se fazer uma reflexão. Galaaz venceu na verdade duas provas no episódio da tentação no castelo do rei Brutus. A primeira foi a luxúria, da qual foi vencedor ao rechaçar a donzela. A segunda prova é quando pôs a sua própria castidade em risco para salvar a vida da jovem. Neste sentido pode-se afirmar que Galaaz atingiu o máximo grau na atitude de auxiliar o próximo, um dos pilares do cristianismo. Mais importante que realizar o seu maior desejo de encontrar o Santo Graal, e para tal havia a necessidade de permanecer virgem, Galaaz pensou primeiro no outro, isto é, em manter a vida da donzela. Essa atitude reforçava o seu caráter de eleito, o que acaba por concretizar a ação de morte que a donzela aplica em si mesma, morte permitida por Deus (ZIERER, 2011, p. 32-33).

No caso de Persival, outro dos cavaleiros eleitos, quando viu a donzela grega e dela se enamorou, pensou primeiro no desejo dele próprio, ao qual não sucumbiu pelo auxílio divino (a voz que veio do Céu). E Boorz também não conseguiu impedir os efeitos do feitiço impetrado contra ele. Daí o 
fato de a presença feminina ser mais um indício do caráter da eleição de Galaaz frente ao Graal e da sua superioridade espiritual com relação aos seus companheiros.

Alguns elementos materiais sublinham a superioridade de Galaaz em relação aos seus dois companheiros: ele ser o único que senta no assento perigoso na távola redonda, destinado ao eleito (outros que tentassem a aventura morreriam) (DSG, 1995, p. 30), retira a espada do Pedrão (DSG, 1995, p. 32) e recebe o escudo branco da cruz vermelha (DSG, 1995, p. 53). A cruz do escudo havia sido feita com o sangue das narinas de Josefes, filho de José de Arimatéia e o escudo com a cruz vermelha lembra o símbolo dos cruzados e das ordens militares, como os templários. Depois Galaaz recebe ainda uma segunda espada, a espada da estranha cinta (DSG, 1995, p. 313), que só pode ser desembainhada por ele. Todos esses objetos e ações indicavam o seu papel de escolhido para encontrar o Santo Graal.

Outros episódios ainda confirmam o caráter especial do eleito: o fato de ele conseguir expulsar o demônio (DSG, 1995, p. 301), curar uma leprosa que veste a sua estamenha (DSG, 1995, p. 307) e também fazer um paralítico andar (DSG, 1995, p. 454-455), ações em analogia com os feitos de Jesus.

É Galaaz quem também possui as mais altas revelações da Demanda, vendo coisas que os olhos corporais não poderiam ver. Após uma visão mais profunda, o Santo Graal e Galaaz são arrebatados ao Céu pelos anjos. Ao mesmo tempo o reino arturiano entra em declínio com a morte dos cavaleiros e a invasão do reino pelo rei Mars, marido de Isolda, que destrói a távola redonda.

\section{O Muçulmano que se tornou cristão: 0 "bom cavaleiro pagão", Palamades}

Palamades exemplifica na narrativa a religião muçulmana e a necessidade de conversão segundo a ótica cristã. Ele é considerado um bom cavaleiro, chamado de o "bom cavaleiro pagão" e na Demanda sua principal atribuição é perseguir a besta ladradora, monstro que havia matado os seus onze irmãos. Enquanto não se converte ao cristianismo a sua perseguição a esse animal se mostra inútil. Porém uma vez luta com Galaaz, o melhor de todos os cavaleiros devido a sua pureza espiritual, e perde o combate. 0 "puro dos puros" exige, para Ihe poupar a vida, que Palamades se convertesse ao cristianismo. Este aceita e imediatamente suas feridas são curadas (DSG, 1988, p. 431). 0 episódio destaca a importância de Galaaz e a defesa da religião cristã pelas armas, fazendo que um muçulmano se tornasse cristão.

A conversão também é benéfica ao cavaleiro Palamades, pois após esta ação acontecer, as suas feridas são curadas por milagre divino e ocorre ainda a sua possibilidade de matar a besta ladradora. Este animal demoníaco é então destruído pelo cavaleiro, mostrando mais uma vitória do 
cristianismo contra as forças do mal. Devido ao seu bom coração e a sua adesão ao cristianismo, Palamades se torna apto a ver o Santo Graal. Encontrar o Santo Vaso na narrativa é um atributo somente dos bons cavaleiros, que são conduzidos pelo predestinado Galaaz. É importante salientar o papel cruzadístico de Galaaz na conversão dos islâmicos ao cristianismo, mostrando um importante traço do modelo do cavaleiro cristão.

\section{Cavaleiros Pecadores e Maus: Galvão e Morderete}

Além dos que caíram no pecado do adultério como Lancelot e Tristão, ou de outros pecadores, existem ainda na Demanda aqueles que representam a antítese do bom combatente. Não respeitam 0 código da cavalaria: mentem, atacam donzelas, matam à traição. Esses cavaleiros incidem nos erros da ira, inveja, orgulho e luxúria (ver quadro 1).

No manual de Ramon Llull voltado aos nobres, O Livro da Ordem de Cavalaria, o autor também defende o modelo do cavaleiro cristão, tal como a Demanda. Ele afirma que os cavaleiros deveriam seguir as sete virtudes, as três teologais (fé, esperança e caridade) e as quatro cardeais (justiça, prudência, fortaleza e temperança). Ao mesmo tempo deveriam proteger o cristianismo e os fracos, lutar contra os infiéis, garantir a manutenção da ordem social e evitar os sete pecados capitais (ira, avareza, preguiça, inveja, luxúria, gula e orgulho).

O grupo de maus cavaleiros na Demanda, no qual se inserem Galvão e Morderete (ver Quadro 1) realizam a luxúria com maldade, atacando donzelas e matando seus pais e irmãos. São eles os representantes dos cavaleiros criticados por Llull e que deveriam ser perseguidos, segundo o filósofo, pelos bons cavaleiros.

Galvão, por exemplo, que em outras narrativas é valorizado como exemplo de cavaleiro cortês, é explicitamente chamado na Demanda de "o cavaleiro do diabo". Ele é mentiroso e nega os valores do cavaleiro cortês. Mata mesmo ao saber que determinados cavaleiros são seus companheiros da távola redonda, mata cavaleiros desarmados e feridos, ataca mulheres. Erec afirma antes de morrer que ele desrespeitava o código da cavalaria:

- Ai dom Galvão, que é isto que dizeis? Lembrai-vos do juramento e da homenagem da mesa redonda [...] certamente se me matares sereis perjuro e desleal e jamais tereis por isso honra [...] porque estou ferido em tantos lugares que tanta força tenho como um cavaleiro morto." (DSG, 1988, p. 267) (grifo nosso).

Mesmo assim Galvão não desiste de seu intento e mata um cavaleiro que não estava em condições de lutar. Além disso, mente a Persival afirmando que não havia matado parentes dele, 
quando na verdade havia matado seu pai e irmãos, indicando a sua covardia. Quanto a Morderete é o causador da morte do próprio pai, o rei Artur. São exemplos de cavaleiros cobiçosos e que colocam em risco a ordem feudal.

\section{Cavaleiros Pecadores e o Orgulho: Erec mata a irmã}

De acordo com a lógica da Demanda, vários cavaleiros são pecadores e por este motivo não conseguirão ver outra vez o Santo Graal. É o caso de Erec. Embora até um ponto do relato seja considerado um bom cavaleiro, entra numa armadilha criada por uma figura feminina, da qual não consegue sair com sucesso. Ele está preso aos rígidos códigos da cavalaria que afirmam que um combatente deve manter a palavra dada.

É interessante ressaltar que segundo a ótica da Demanda, somente os cavaleiros que possuíssem virtudes seriam vitoriosos na busca do Graal. Neste sentido, podemos dizer que Galaaz é possuidor das sete virtudes, as três teologais (fé, esperança e caridade), as quatro cardeais (justiça, prudência, fortaleza e temperança) e ainda outras como a bondade e a humildade.

Já os cavaleiros pecadores e que na ótica da narrativa necessitavam do controle da sua agressividade, caem em um ou mais dos sete pecados capitais e por isso não conseguem ver outra vez o Graal. O pecado mais importante neste romance é a luxúria. A virgindade é o principal "trunfo" de Galaaz que o opõe a seu pai, Lancelot, que embora bom nas armas, não consegue ser vitorioso na Demanda.

Quanto a Erec, sabemos que já havia incorrido nesse pecado, na medida em que cai uma vez na fonte da Virgem, onde quem não fosse casto ficaria paralisado. Ele é ajudado pelas damas da fonte que o ajudam a sair dali. No entanto, a luxúria não é o seu principal pecado e sim, o orgulho.

Vejamos o que ocorre. Uma donzela pede a Erec um dom e ele aceita sem saber do que se trata. Em muitas aventuras arturianas a promessa de dar o dom a um estranho tem consequências desastrosas. Mais tarde ao reencontrar a sua irmã, a donzela explicita seu desejo: "Erec, vós me deveis um dom o qual vos ontem recordei, e quero quantos saibam aqui estão. [...] - Erec eu peço a cabeça da donzela que senta perto de ti." (DSG, 1988, p. 240). Isto é, a morte da irmã dele. Como segundo a ótica cavaleiresca um cavaleiro não poderia mentir e ser perjuro, Erec é levado a cometer o pecado mortal.

Aqui é interessante uma reflexão: Erec ao se concentrar na impossibilidade de um cavaleiro mentir, se preocupou mais com a sua "honra", isto é manter a palavra dada, do que conservar a vida de um ser humano inocente, o que era ainda agravado pelo fato de a jovem a ser eliminada ser do seu 
próprio sangue. Daí o fato de podermos dizer que ele se insere no pecado do orgulho. É possível contrastar a ação de Erec que mata a irmã, com a de Galaaz, no episódio do Castelo do rei Brutus. Galaaz, naquela ocasião era capaz de sacrificar a sua virgindade e seu papel de eleito para salvar a vida da donzela. Já Erec em vez de pensar na irmã, demonstra egoísmo e a mata para manter o seu status de cavaleiro que não mentia.

Tentando resolver o problema e impedir a morte dela, Erec propõe que outros o matassem, e ante a negativa, afirma que teria mesmo que assassinar a irmã:

\footnotetext{
- Que dizeis, senhores? Disso não posso escapar a menos que me mateis porque enquanto viva, não me afastarei da promessa que prometer, mas se me matardes, ficará ela.Ora fazei qual tiverdes de melhor: ou me matais ou matarei eu a ela, porque muito de coração quero receber esta morte [...] (DSG, 1988, p. 243) (grifo nosso)
}

Assim, efetivamente cumpre o dom solicitado pela donzela má. Após esta ação fica na Demanda em aventuras a esmo, desejando a morte, até que luta com o desleal Galvão, que não respeita o fato de Erec estar ferido e o mata em combate.

\section{Cavaleiros Pecadores: Leonel e a ira}

Leonel, outro membro da távola redonda, era até então considerado um bom cavaleiro, quando é atacado por guerreiros em maior número. Neste momento vê seu irmão Boorz e espera ser salvo por ele. Boorz, um dos cavaleiros eleitos, fica num impasse, pois ao mesmo tempo em que seu irmão corria risco de morrer, viu também uma donzela prestes a ser violentada. Por isso, Boorz reza pela salvação do irmão e salva a jovem, na medida em que auxiliar os fracos e indefesos é um dos atributos do bom combatente, segundo a ótica da cavalaria.

Depois de salvo por milagre, Leonel é tomado de fúria e quer matar o irmão. Um ermitão the explica o milagre divino que havia sido feito, mas mesmo assim o cavaleiro não desiste do seu intento. Boorz se recusa a lutar e alguns indivíduos buscam protegê-lo. Em primeiro lugar se interpõe entre os dois um religioso, assassinado por Leonel. A morte de um clérigo era um pecado gravíssimo segundo 0 código da cavalaria e já desde o século X, com a Paz de Deus, a Igreja Católica proibia a sua morte por cavaleiros. Depois Calogrenante, companheiro da távola redonda, também tenta impedir o ataque de Leonel contra Boorz, mas também morre. Os assassinatos sem motivo acentuam a gravidade das ações de Leonel: duas mortes unicamente porque havia sido tomado pelo pecado da ira e um deles 
contra um eremita, um homem puro. Depois disso, Boorz resolve lutar contra 0 assassino, mas Deus envia o fogo para separá-los e impedir que cometesse o fratricídio (DSG, 1995, p. 144).

A atitude de Leonel (a ira), bem como a de outros cavaleiros pecadores mostrados antes denotam a necessidade, segundo a ótica cristã, de que a violência da nobreza fosse "civilizada" através do incentivo que os nobres seguissem os ideais da Igreja como rezar, se confessar e realizar combates contra os inimigos da Cristandade, de forma que a ação dos cavaleiros não pusesse em risco a ordem social.

\section{Conclusão}

Ao longo do período medieval as atitudes da nobreza foram gradativamente controladas através da educação e buscou-se suavizar o caráter agressivo desse grupo através de normas de comportamento e do controle das emoções. Foram estimuladas ações comportamentais, com a criação de modos de comportar-se à mesa e atitudes de conduta "corteses" aos cavaleiros.

É bom lembrarmos que havia a necessidade de se refrear o que Elias chama de "brutalidade" desse grupo, que adotava atitudes cruéis com relação aos inimigos, buscando tomar suas terras e matar os seus dependentes para dar prejuízo ao oponente, uma vez que "o prazer de matar e torturar era grande e socialmente permitido" (ELIAS, v. I, 1994, p. 192), daí a necessidade, gradativamente, de controle sobre suas ações.

Essas atitudes da nobreza eram uma ameaça à sobrevivência da própria estrutura da sociedade, uma vez que nobres atacavam outros nobres, o que abriu a possibilidade na Idade Média Central e Baixa Idade Média para o fortalecimento do rei, com o apoio de outras categorias, como os burgueses. Os romances corteses mostram uma realidade que não existe mais: os cavaleiros como centro da sociedade ao passo que na prática comerciantes e o monarca começavam a se fortalecer.

Através da novela de cavalaria A Demanda do Santo Graal é possível perceber elementos da ideologia cavaleiresca. A Demanda representa um desejo de controle dos cavaleiros e de re-incutir os ideais de cavalaria que vinham desde as Cruzadas, transformando os cavaleiros em defensores do cristianismo e buscando suavizar a sua violência no intuito de conservação das estruturas da sociedade feudal.

Ao lado da ordem, o herói mais representativo da novela é Galaaz. O melhor cavaleiro, segundo a concepção da narrativa, é o cristão mais puro, que põe a defesa da religião em primeiro lugar através da sua conduta de rezar, jejuar, confessar-se e de usar a estamenha. Além disso, 
mantém a sua virgindade e humildade, jamais se vangloriando de suas ações. $O$ cavaleiro também luta pelo fortalecimento da fé cristã ao perseguir um muçulmano, a quem obriga se converter ao cristianismo, um dos ideais das Cruzadas.

Ao lado das ações do cavaleiro perfeito, há os exemplos do que deveria ser evitado: cavaleiros que desrespeitavam os fracos e as mulheres e que não respeitavam o código da cavalaria, colocando em risco o funcionamento da sociedade, cavaleiros estes que deveriam ser reorientados, suavizando as suas ações através da difusão de obras literárias. A Demanda do Santo Graal e o Livro da Ordem de Cavalaria valorizam o cavaleiro obediente à Igreja e aos seus superiores, como o monarca.

É possível afirmar que o modelo do cavaleiro cortês estava sendo combatido por obras como $A$ Demanda do Santo Graal porque os nobres, muitas vezes em busca de aventuras, criavam problemas na sociedade. Já o modelo do cavaleiro cristão proposto por Llull e na Demanda pretendia manter o controle da nobreza em relação aos outros grupos sociais e "civilizá-la", reeducando os bellatores em direção aos valores cristãos.

\section{Bibliografia}

\section{FONTES}

A Demanda do Santo Graal. (ed. Crítica e fac-similar de Augusto Magne). Rio de Janeiro: Instituto Nacional do Livro, v. I (1955) e v. II (1970).

A Demanda do Santo Graal. Ed. de Irene Freire Nunes. Lisboa: Imprensa Nacional/Casa da Moeda, 1995.

A Demanda do Santo Graal. Texto sobre os cuidados de Heitor Megale. São Paulo: T.A. Queiroz, 1988. CHRÉTIEN DE TROYES. "Lancelot ou o Cavaleiro da Charrete". In: Romances da Távola Redonda (Trad. Rosemary Abílio). São Paulo: Martins Fontes, 1991, p. 119-197.

CHRÉTIEN DE TROYES. Perceval ou o Romance do Graal. (Trad. Rosemary Abílio). São Paulo: Martins Fontes, 1992.

RAMON LLULL. O Livro da Ordem de Cavalaria(1279-1283). Tradução de Ricardo da Costa. São Paulo: Instituto Brasileiro de Filosofia e Ciência "Raimundo Lúlio" (Ramon Llull), 2000.

\section{ESTUDOS}

BUESCU, Maria Gabriela C. Perceval e Galaaz, Cavaleiros do Graal. Lisboa: Instituto de Cultura Portuguesa, 1991.

CARDINI, O Guerreiro e o Cavaleiro. In: LE GOFF, Jacques. O Homem Medieval. Lisboa: Editorial Presença, 1989, p. 57-78.

CARDINI, F. Guerra e Cruzada. In: LE GOFF, Jacques; SCHMITT, Jean-Claude. Dicionário Temático do Ocidente Medieval. São Paulo: Imprensa Oficial/EDUSC, 2002, v. 1, p. 473-487.

CHORA, Ana Margarida. Os Cavaleiros do Graal e o Anti-Heroísmo Hagiográfico. Medievalista on line. Lisboa, Instituto de Estudos Medievais, v. 12, Julho-Dezembro 2012, p. 1-29. Disponível em: http://www2.fcsh.unl.pt/iem/medievalista/ Acesso em 30/01/2013.

DUBY, G. A Sociedade Cavaleiresca. São Paulo: Martins Fontes, 1989. 
DUBY, Georges. "História Social e Ideologias das Sociedades." In: LE GOFF, Jacques e NORA, Pierre. História: Novos Problemas. Rio de Janeiro: Francisco Alves, 1976.

DUBY, Georges. As Três Ordens ou o Imaginário do Feudalismo. Lisboa: Editorial Estampa, 1982.

ELIAS, Norbert. O Processo Civilizador. Rio de Janeiro: Jorge Zahar Ed., 1994, 2 vols.

FERNANDES, Rául César. "Maravilhas e Aventuras n'A Demanda do Santo Graal. Espéculo". Revista de Estudos Literários. Madrid, Universidad Complutense de Madrid, 2010, v. 45, p. 1-14. Disponível em: www.ucm.es/info/especulo/numero45/sinalesp.html, acesso em 20/01/2013

FLORI, Jean. A Cavalaria. São Paulo: Madras, 2005.

LE GOFF, Jacques. O Imaginário Medieval. Lisboa: Editorial Estampa, 1994.

LE ROUX, Françoise e GUYONVARC'H, Christian-J. A Civilização Celta. Lisboa: Europa-América, 1990.

MARTIN, Hérvé. Mentalités Médiévales XI-XV siècle. Paris: PUF, 1996.

MEGALE, Heitor. O Jogo dos Anteparos. A Demanda do Santo Graal: A Estrutura Ideológica e a Construção da Narrativa. São Paulo: T. A. Queiroz Ed., 1992.

MOISÉS, Massaud. A Literatura Portuguesa. Rio de Janeiro: Cultrix, 1975.

MONGELLI, Lênia Márcia. Por quem Peregrinam os Cavaleiros de Artur. São Paulo: Íbis, 1995.

PASTOREAU, Michel. No Tempo dos Cavaleiros da Távola Redonda. São Paulo: Companhia das Letras, 1989.

PEREIRA, Rita de Cássia. O Herói e o Soberano - Modelo Heróico e Representações da Soberania na Demanda do Santo Graal. Dissertação de Mestrado em História. São Paulo: Universidade de São Paulo, 1996.

SCHMITT, Jean-Claude. O Corpo das Imagens. São Paulo: EDUSC, 2007.

ZIERER, A. M. S. Virtudes e Vícios dos Cavaleiros n' A Demanda do Santo Graal. In: MONGELLI, Márcia (Org.). De Cavaleiros e Cavalarias. Por terras de Europa e Américas. São Paulo: Humanitas, 2012, p. 37-47. Disponível em:

http://editora.fflch.usp.br/sites/editora.fflch.usp.br/files/37-47.pdf

Acesso em 20/01/2013.

ZIERER, Adriana. Literatura e História n'A Demanda do Santo Graal: o rei, o cavaleiro e a mulher. In: ZIERER, Adriana, FEITOSA, Márcia Manir (Orgs). Literatura e História Antiga e Medieval: olhares interdisciplinares. São Luís: EDUFMA, 2011, p. 13-44.

ZIERER, A. M. S. O Livro da Ordem de Cavalaria, de Ramon Llull: uma proposta pedagógica de sociedade na Idade Média. Notandum. São Paulo (USP), v.27, 2011b, p.171-187. Disponível em: www.hottopos.com/notand27/index.htm Acesso em 20/01/2013. 